\title{
Hypoglycaemic effect of the methanolic extract of Aporusa lindleyana leaves on rats
}

\author{
B.L.C. Samanmali ${ }^{1 *}$, Mangala Gunatilake ${ }^{2}$, Ranil D. Guneratne ${ }^{1}$ and T.R.K. Perera ${ }^{3}$ \\ ${ }^{1}$ Department of Chemistry, Faculty of Science, University of Colombo, Colombo 03. \\ ${ }^{2}$ Department of Physiology, Faculty of Medicine, University of Colombo, Kynsey Road, Colombo 08 \\ ${ }^{3}$ Animal House, Faculty of Medicine, University of Colombo, Kynsey Road, Colombo 08.
}

\begin{abstract}
Aporusa lindleyana is a medicinal plant, which is claimed to have a hypoglycaemic potential. This study was carried out to determine the hypoglycaemic effect, toxicity of long term usage and the phytochemistry of tender leaves of $A$. lindleyana. The hypoglycaemic effect of the methanolic leaf extract of $A$. lindleyana on the fasting and random blood glucose concentrations and the glucose tolerance were tested using three oral doses of the extract $(100,400,800 \mathrm{mg} / \mathrm{kg})$ in Sprague-Dawley rats. Sub-acute toxicity studies were performed after treating the rats for 28 consecutive days with the highest dose and were tested for different parameters. The results exhibit a dose dependent hypoglycaemic effect with the maximum blood glucose reduction observed at the $4^{\text {th }}$ hour after the treatment. All three tested doses significantly reduced the fasting blood glucose concentration 4 hours after treatment. Only the intermediate and the highest doses showed a significant reduction in random blood glucose concentration in normoglycaemic non-fasted rats and a significant glucose tolerance, when tested on an oral glucose load. There was no significant difference in the physical and biochemical parameters in rats treated with the extract for 28 days compared to the control group. The extract contained alkaloids, saponins, flavonoids and leucoanthocyanins as revealed by phytochemical screening. It can be concluded that $A$. lindleyana leaves exhibit hypoglycaemic activity since they significantly $(\mathrm{p}<0.05)$ reduce the blood glucose concentration in normoglycaemic rats and significantly $(\mathrm{p}<0.05)$ enhances the glucose tolerance. The long term use of the leaf extract does not produce any toxic signs in rats.
\end{abstract}

Keywords: Aporusa lindleyana, blood glucose concentration, diabetes mellitus, hypoglycaemic effect, toxicity.

\section{INTRODUCTION}

Diabetes mellitus is a chronic metabolic disorder characterized by hyperglycaemia (Colledge et al., 2010).
It is considered as a major public health problem and one of the leading causes of deaths in the world today. It is estimated that 370 million people will be affected by this disorder by the year 2030 (Kumar \& Clark, 2009). Thus tight control of diabetes is essential.

The chemotherapy of diabetes mellitus includes oral hypoglycaemic drugs and insulin, but these agents possess many side effects (Joint Formulary Committee, 2009). Thus it is important to find a more effective hypoglycaemic agent with fewer side effects. There are herbal preparations used in Ayurvedic and other traditional systems of medicine, which are claimed to have a hypoglycaemic potential with fewer side effects (Ediriweera \& Ratnasooriya, 2009). Many studies have been conducted to evaluate the hypoglycaemic effect of such medicinal plants having hypoglycaemic potential (Fernandopulle et al., 1994; Ratnasooriya et al., 2004; Kasiviswanath et al., 2005; Sharma et al., 2011).

Aporusa lindleyana (Wight) Baill, commonly known as 'Kebella' in Sinhala is an angiosperm medicinal plant belonging to the family Euphorbiaceae (Dasanayake \& Clayton, 1997). The tender leaves of the plant are prescribed to diabetic patients as a food in Sri Lankan traditional medicinal system (Department of Ayurveda, 2004) and people use these leaves in the belief that the blood glucose concentrations will be reduced. The analgesic and antibacterial effects of the bark extract of the plant and the antioxidant activity of the root of the plant have also been scientifically proven (Badami et al., 2005; Lingadahalli et al., 2008). Only one report is available on the hypoglycaemic activity of the aqueous and alcoholic 
extracts of the roots (Jayakar \& Suresh, 2003), but no study has scientifically proven the hypoglycaemic effect of the tender leaves of the plant. The objectives of this study were (a) to scientifically evaluate the hypoglycaemic effect of a methanolic extract of the tender leaves of $A$. lindleyana plant, (b) to carry out a chemical investigation of the phytochemicals present in the leaf extract, and (c) to evaluate the safety of long - term use of $A$. lindleyana by conducting sub-acute toxicity studies.

\section{METHODS AND MATERIALS}

\section{Plant collection and identification}

Tender leaves of $A$. lindleyana were collected from Panadura in the Kalutara District and the plant was identified at the Department of Plant Sciences, Faculty of Science, University of Colombo. A voucher specimen (BLCS/001) was prepared and placed in the herbarium of the Department of Plant Sciences, University of Colombo.

\section{Preparation of the leaf extract}

The collected tender leaves were washed under running water, shade dried for two weeks, cut into small pieces and powdered with a domestic electric blender (Sumeet Machines Pvt. Ltd., Nasik, India). The powdered leaves $(1.60 \mathrm{~kg})$ were macerated with distilled methanol $(16.0 \mathrm{~L})$ for $72 \mathrm{~h}$. After the extraction, the solvent was evaporated to dryness under reduced pressure at $40{ }^{\circ} \mathrm{C}$ in a rotary evaporator (BUCHI R-200 operating with a Vaccubrand MZ-ZC-NT vacuum pump) and finally freeze dried (Rajagopal et al., 2008). The required dose of the obtained product was suspended in $1.0 \mathrm{~mL}$ of distilled water using a mortar and a pestle prior to administration to the rats.

\section{Experimental animals}

Healthy, adult, male, Sprague-Dawley rats weighing $200-250 \mathrm{~g}$, bred in the Animal House, Faculty of Medicine, University of Colombo were used in this study. The experimental animals were housed in standard plastic rat cages in the animal house under standard environmental conditions (temperature: $28-31{ }^{0} \mathrm{C}$, photoperiod: approximately $12 \mathrm{~h}$ natural light per day, relative humidity: $50-55 \%$ ) with free access to commercially available pelleted food and tap water. Except at the time of experimental procedure, the animals were handled only during cage cleaning. The experiments were conducted in accordance with the internationally accepted guidelines and The Rules for Laboratory Animal Use of the Ethics Review Committee of Faculty of Medicine, University of Colombo for animal experimentation.

\section{Selection of doses of methanolic leaf extract}

The lowest, intermediate and highest doses of the methanolic leaf extract were selected from a series of doses after conducting a preliminary study (Dhawan \& Srimal, 1984).

\section{Effect of methanolic leaf extract on fasting blood glucose concentration}

Thirty rats were randomly divided into 5 equal groups and fasted overnight for $16 \mathrm{~h}$, but water was allowed ad libitum. The initial fasting blood glucose concentration of the rats was measured (pre treatment). Immediately afterwards the rats were orally treated (single dose treatment) in the following manner (Dayananda et al., 2008; Jayakody \& Ratnasooriya, 2008);

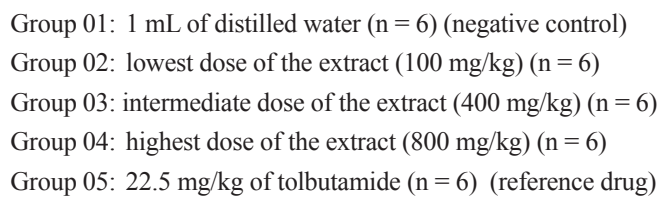

Blood $(0.25 \mathrm{~mL})$ was collected hourly for $4 \mathrm{~h}$ after the treatment to determine the blood glucose concentration.

\section{Effect of methanolic leaf extract on random blood glucose concentration}

Thirty rats were randomly divided into 5 equal groups and treated orally (single dose treatment) in the manner described above (Group 01 - Group 05) (Dayananda et al., 2008; Jayakody \& Ratnasooriya, 2008).

Blood samples $(0.25 \mathrm{~mL})$ were collected $1 \mathrm{~h}$ prior to commencement of the treatment, hourly for $4 \mathrm{~h}$ after the treatment and the blood glucose concentrations were measured.

\section{Effect of methanolic leaf extract on glucose tolerance}

Thirty rats were randomly divided into 5 equal groups and fasted overnight for $16 \mathrm{~h}$. The rats were then treated orally (single dose treatment) in the manner described in the previous experiments (Group 01 - Group 05). 
After $1 \mathrm{~h}$, all the rats were orally loaded with $5 \mathrm{~mL} / \mathrm{kg}$ of $50 \%(\mathrm{w} / \mathrm{v})$ glucose solution. Blood glucose concentrations of these rats were measured immediately prior to the treatment and hourly for $4 \mathrm{~h}$ after glucose administration (Jayakody \& Ratnasooriya, 2008).

\section{Estimation of blood glucose concentration}

Blood was collected from the tail vein of the rats under light ether anesthesia using aseptic precautions (Dayananda et al., 2008; Parasuraman et al., 2010). Serum of the collected blood was separated by centrifugation at $3000 \mathrm{rpm}$ for $10 \mathrm{~min}$ and the serum glucose concentration was determined spectrophotometrically (6300, Jenway LTD, Dunmow, UK) using Randox glucose oxidase assay kit (Randox Laboratories, Antrium, UK) at $500 \mathrm{~nm}$ wavelength (Barham \& Trinder, 1972; Henry et al., 1974).

\section{Investigation of toxicological effects of $\boldsymbol{A}$. lindleyana}

Twelve rats were randomly divided into two groups $(\mathrm{n}=6)$ and treated orally daily (single treatment) in the following manner for 28 consecutive days to determine the sub-acute toxicity (Dhawan \& Srimal, 1984; Dayananda et al., 2008; OECD, 2008).

Group 1: $1 \mathrm{~mL}$ of distilled water (Control group)

Group 2: highest dose of leaf extract ( 800 mg/kg)

During this period the animals were observed for signs of toxicity (diarrhoea, salivation, lacrimation, squinted eyes, change of fur colour, loss of hair, excretion of fur and behavioural abnormalities).

The food and water intakes and the body weights of the animals were determined prior to the commencement of the treatment and weekly during the treatment. Blood samples $(1.5 \mathrm{~mL})$ were collected from the tail vein of these rats after 28 days under aseptic conditions. Serum was separated and the serum glutamic pyruvic transaminase (SGPT), serum glutamic-oxaloacetic transaminase (SGOT), blood urea nitrogen (BUN) and creatinine levels were determined using a chemistry analyzer (POINTE 180, USA) and reagent kits (Tietz, 1976; Huang et al., 2006; Peake \& Whiting, 2006).

\section{Phytochemical screening}

A preliminary phytochemical screening was performed on the freeze dried product of the methanolic leaf extract of $A$. lindleyana according to the standard methods for alkaloids, saponins, unsaturated sterols, triterpenes, flavonoids, leucoanthocyanins, tannins and polyphenols (Farnsworth, 1978).

\section{Statistical analysis}

Results of the experiments carried out for the evaluation of hypoglycaemic effect were statistically analyzed using one way analysis of variance (ANOVA) followed by Dunnett's multiple comparison test. Blood glucose concentrations of the drug treated groups were compared with the corresponding negative control group at each time point. For the toxicological studies, values of the control group and the treatment groups were compared using Mann Whitney U test. All the data were expressed as mean \pm standard error of mean (SEM). Probability values (p) less than 0.05 were considered as statistically significant. Minitab version 15.0 was used for the statistical analysis.

\section{RESULTS}

\section{Evaluation of hypoglycaemic effect}

\section{Effect of methanolic leaf extract on fasting blood glucose concentration}

As shown in Table 1, all three doses showed a significant hypoglycaemic effect at the $4^{\text {th }}$ hour after treatment as compared to the respective control group. The highest dose reduced the fasting blood glucose concentration at all the tested hours similar to the reference drug tolbutamide.

\section{Effect of methanolic leaf extract on random blood glucose concentration}

The lowest dose of the extract did not show a significant blood glucose reduction in the experimental time period. Both the intermediate and the highest doses showed a significant reduction in blood glucose concentration at the $4^{\text {th }}$ hour after administration of the extract. The reference drug (tolbutamide) reduced the blood glucose concentration significantly at all the tested hours after treatment (Table 2).

\section{Effect of methanolic leaf extract on glucose tolerance}

The lowest dose of the leaf extract did not show a significant glucose tolerance during the experimental time period (4 hours), whereas the intermediate and the highest doses showed a tolerance after administration of a glucose load (Table 3). 
Table 1: The mean effect of oral administration of methanolic leaf extract of A. lindleyana on fasting blood glucose concentration in rats

\begin{tabular}{|c|c|c|c|c|c|}
\hline \multirow{3}{*}{ Treatment } & \multicolumn{5}{|c|}{ Glucose concentration $(\mathrm{mg} / \mathrm{dL})($ mean $\pm \mathrm{SEM}, \mathrm{n}=6$ per group $)$} \\
\hline & \multirow[t]{2}{*}{ Pre treatment } & \multicolumn{4}{|c|}{ Post treatment } \\
\hline & & $1 \mathrm{~h}$ & $2 \mathrm{~h}$ & $3 \mathrm{~h}$ & $4 \mathrm{~h}$ \\
\hline $\begin{array}{l}\text { Distilled water } \\
\text { (negative control) }\end{array}$ & $96.4 \pm 1.4$ & $97.2 \pm 0.6$ & $95.5 \pm 1.6$ & $95.1 \pm 1.1$ & $94.6 \pm 0.8$ \\
\hline $\begin{array}{l}\text { Lowest dose } \\
(100 \mathrm{mg} / \mathrm{kg})\end{array}$ & $92.6 \pm 1.5$ & $94.8 \pm 1.4$ & $90.6 \pm 2.6$ & $87.1 \pm 2.1$ & $81.2 \pm 2.9^{*}$ \\
\hline $\begin{array}{l}\text { Intermediate dose } \\
(400 \mathrm{mg} / \mathrm{kg})\end{array}$ & $95.5 \pm 1.1$ & $91.2 \pm 2.3$ & $87.4 \pm 1.8$ & $83.2 \pm 2.1^{*}$ & $77.8 \pm 2.8^{*}$ \\
\hline $\begin{array}{l}\text { Highest dose } \\
(800 \mathrm{mg} / \mathrm{kg})\end{array}$ & $93.7 \pm 1.1$ & $89.4 \pm 1.1^{*}$ & $82.8 \pm 2.5^{*}$ & $80.5 \pm 1.3^{*}$ & $69.4 \pm 1.5^{*}$ \\
\hline $\begin{array}{l}\text { Tolbutamide } \\
(22.5 \mathrm{mg} / \mathrm{kg} \text { ) } \\
\text { (reference drug) }\end{array}$ & $94.6 \pm 1.6$ & $69.8 \pm 2.2^{*}$ & $66.0 \pm 2.8^{*}$ & $65.0 \pm 4.2^{*}$ & $65.5 \pm 4.3^{*}$ \\
\hline
\end{tabular}

Values are significant *at $\mathrm{p}<0.05$ compared with the respective control

Table 2: The mean effect of oral administration of the methanolic leaf extract of A. lindleyana on random blood glucose concentration in rats

\begin{tabular}{|c|c|c|c|c|c|}
\hline \multirow{3}{*}{ Treatment } & \multicolumn{5}{|c|}{ Glucose concentration $(\mathrm{mg} / \mathrm{dL})($ Mean $\pm \mathrm{SEM}, \mathrm{n}=6$ per group $)$} \\
\hline & \multirow[t]{2}{*}{ Pre treatment } & \multicolumn{4}{|c|}{ Post treatment } \\
\hline & & $1 \mathrm{~h}$ & $2 \mathrm{~h}$ & $3 \mathrm{~h}$ & $4 \mathrm{~h}$ \\
\hline $\begin{array}{l}\text { Distilled water } \\
\text { (negative control) }\end{array}$ & $130 \pm 2$ & $131 \pm 2$ & $128 \pm 2$ & $130 \pm 2$ & $129 \pm 3$ \\
\hline $\begin{array}{l}\text { Lowest dose } \\
(100 \mathrm{mg} / \mathrm{kg})\end{array}$ & $131 \pm 3$ & $131 \pm 2$ & $130 \pm 2$ & $126 \pm 2$ & $124 \pm 2$ \\
\hline $\begin{array}{l}\text { Intermediate dose } \\
(400 \mathrm{mg} / \mathrm{kg})\end{array}$ & $131 \pm 1$ & $127 \pm 2$ & $125 \pm 3$ & $123 \pm 2$ & $114 \pm 3^{*}$ \\
\hline $\begin{array}{l}\text { Highest dose } \\
(800 \mathrm{mg} / \mathrm{kg})\end{array}$ & $132 \pm 2$ & $127 \pm 2$ & $125 \pm 2$ & $120 \pm 1^{*}$ & $113 \pm 3^{*}$ \\
\hline $\begin{array}{l}\text { Tolbutamide } \\
\text { ( } 22.5 \mathrm{mg} / \mathrm{kg} \text { ) } \\
\text { (reference drug) }\end{array}$ & $133 \pm 4$ & $109 \pm 5^{*}$ & $100 \pm 5^{*}$ & $99.9 \pm 2.3^{*}$ & $98.1 \pm 4.5^{*}$ \\
\hline
\end{tabular}

\section{Investigation of toxicological effects of $A$. lindleyana}

During the experimental period none of the rats in the treated and control groups showed signs of toxicity, i.e., diarrhoea, salivation, lacrimation, squinted eyes, change of fur colour, loss of hair, excretion of fur and behavioural abnormalities. Further, none of the treated or control rats died. As shown in Table 4, the highest dose of the extract did not significantly affect the food intake, water intake and body weight of rats. Treatment with the extract over one month did not significantly affect the liver and kidney functions of rats (Table 5).

\section{Phytochemical screening}

Phytochemical screening of the leaf extract revealed the presence of alkaloids, saponins, flavanoids and leucoanthocyanins. 
Table 3: The mean effect of methanolic leaf extract of $A$. lindleyana on glucose tolerance

\begin{tabular}{lccccc}
\hline & \multicolumn{5}{c}{ Glucose concentration $(\mathrm{mg} / \mathrm{dL})($ Mean \pm SEM, $\mathrm{n}=6$ per group) } \\
Treatment & Pre treatment & \multicolumn{4}{c}{ Post treatment } \\
& & $1 \mathrm{~h}$ & $2 \mathrm{~h}$ & $3 \mathrm{~h}$ & $4 \mathrm{~h}$ \\
\hline $\begin{array}{l}\text { Distilled water } \\
\text { (negative control) }\end{array}$ & $92.7 \pm 2.1$ & $121 \pm 3$ & $112 \pm 3$ & $104 \pm 1$ & $98.9 \pm 2.8$ \\
$\begin{array}{l}\text { Lowest dose } \\
(100 \mathrm{mg} / \mathrm{kg})\end{array}$ & $91.0 \pm 2.4$ & $121 \pm 4$ & $111 \pm 2$ & $102 \pm 3$ & $89.4 \pm 4.6$ \\
$\begin{array}{l}\text { Intermediate dose } \\
(400 \mathrm{mg} / \mathrm{kg})\end{array}$ & $92.2 \pm 1.2$ & $120 \pm 3$ & $108 \pm 1$ & $94.2 \pm 2.5^{*}$ & $87.7 \pm 1.8^{*}$ \\
$\begin{array}{l}\text { Highest dose } \\
(800 \mathrm{mg} / \mathrm{kg})\end{array}$ & $89.9 \pm 2.3$ & $112 \pm 2$ & $103 \pm 1^{*}$ & $94.0 \pm 3.7^{*}$ & $85.2 \pm 1.2^{*}$ \\
$\begin{array}{l}\text { Tolbutamide } \\
(22.5 \mathrm{mg} / \mathrm{kg})\end{array}$ & $91.1 \pm 2.3$ & $79.1 \pm 2.6^{*}$ & $73.8 \pm 2.9^{*}$ & $71.8 \pm 1.7^{*}$ & $71.8 \pm 2.0^{*}$ \\
$($ reference drug) & & & & & \\
\hline
\end{tabular}

Values are significant $*$ at $\mathrm{p}<0.05$ compared with the respective control

Table 4: The mean effect of highest dose of methanolic leaf extract of $A$. lindleyana on food intake, water intake and body weight of rats

\begin{tabular}{|c|c|c|c|c|c|c|}
\hline \multirow{2}{*}{\multicolumn{2}{|c|}{ Treatment }} & \multicolumn{5}{|c|}{ (mean $\pm \mathrm{SEM}, \mathrm{n}=6$ per group) } \\
\hline & & \multirow{2}{*}{$\begin{array}{c}\text { Pre treatment } \\
25.9 \pm 0.9\end{array}$} & \multirow{2}{*}{$\frac{1^{\text {st }} \text { week }}{23.4 \pm 0.6}$} & \multirow{2}{*}{$\frac{2^{\text {nd }} \text { week }}{20.9 \pm 0.8}$} & \multirow{2}{*}{$\frac{3^{\text {rd }} \text { week }}{22.9 \pm 1.2}$} & \multirow{2}{*}{$\frac{4^{\text {th }} \text { week }}{24.2 \pm 1.3}$} \\
\hline Food intake (g) & $800 \mathrm{mg} / \mathrm{kg}$ dose & & & & & \\
\hline & Control & $26.9 \pm 1.1$ & $24.9 \pm 0.6$ & $21.3 \pm 1.5$ & $22.8 \pm 0.9$ & $25.4 \pm 0.9$ \\
\hline \multirow[t]{2}{*}{ Water intake $(\mathrm{mL})$} & $800 \mathrm{mg} / \mathrm{kg}$ dose & $49 \pm 2$ & $48 \pm 5$ & $54 \pm 3$ & $57 \pm 3$ & $56 \pm 1$ \\
\hline & Control & $50 \pm 2$ & $51 \pm 4$ & $51 \pm 3$ & $55 \pm 2$ & $53 \pm 3$ \\
\hline \multirow[t]{2}{*}{ Body weight (g) } & $800 \mathrm{mg} / \mathrm{kg}$ dose & $209 \pm 8$ & $210 \pm 10$ & $218 \pm 8$ & $224 \pm 9$ & $229 \pm 7$ \\
\hline & Control & $208 \pm 8$ & $211 \pm 8$ & $219 \pm 8$ & $224 \pm 8$ & $234 \pm 8$ \\
\hline
\end{tabular}

Table 5: The mean effect of methanolic leaf extract of $A$. lindleyana on the liver and kidney functions of rats

\begin{tabular}{lcc}
\hline Parameter & Rat group & Value \\
\hline SGOT (IU/L) & Control & $166 \pm 8$ \\
& Highest dose $(800 \mathrm{mg} / \mathrm{kg})$ & $170 \pm 7$ \\
SGPT (IU/L) & Control & $158 \pm 6$ \\
& Highest dose $(800 \mathrm{mg} / \mathrm{kg})$ & $157 \pm 7$ \\
Creatinine $(\mathrm{mg} / \mathrm{dL})$ & Control & $0.82 \pm 0.05$ \\
& Highest dose $(800 \mathrm{mg} / \mathrm{kg})$ & $0.78 \pm 0.05$ \\
Urea $(\mathrm{mg} / \mathrm{dL})$ & Control & $39.9 \pm 2.2$ \\
& Highest dose $(800 \mathrm{mg} / \mathrm{kg})$ & $40.5 \pm 1.4$ \\
\hline
\end{tabular}

\section{DISCUSSION}

This study investigated the hypoglycaemic potential of the tender leaves of $A$. lindleyana using rats. In the determination of the effects of methanolic leaf extract on fasting blood glucose concentration of rats, the highest dose exhibited a rapid onset of action (within $1^{\text {st }}$ hour) similar to the reference drug, tolbutamide. Tolbutamide is a hypoglycaemic agent prescribed for the treatment of type 2 diabetes mellitus and belongs to the sulphonylurea class that acts mainly by augmenting insulin secretion (Bennett \& Brown, 2003; Joint Formulary Committee, 2009). Rapid hypoglycaemic activity is also evident with the studies carried out with Camellia sinensis (Jayakody 
\& Ratnasooriya, 2008). The duration of action of the $A$. lindleyana leaf extract was prolonged until the $4^{\text {th }}$ hour with the maximum glucose reduction observed at the $4^{\text {th }}$ hour after the treatment (the study period was limited to 4 hours considering the feasibility). All the results of this experiment have revealed a dose dependent hypoglycaemic effect of the $A$. lindleyana extract that could be due to a receptor mediated mechanism (Jayakody \& Ratnasooriya, 2008). However, the amount of blood glucose reduction by the extract was less than that of tolbutamide, suggesting that the potency of the extract is lower than the reference drug.

Hypoglycaemic activity with a maximum blood glucose reduction at the $3^{\text {rd }}$ hour has also been reported in a previous study carried out with aqueous and alcoholic extracts of the bark of the same plant (Jayakar \& Suresh, 2003).

Although the leaf extract showed a hypoglycaemic effect with rapid onset when evaluating the effect on the fasted rats in this study, the effect on random blood glucose concentration of the rats did not show a rapid action. A few studies have reported that some medicinal plants do not show a hypoglycaemic effect with the non-fasted rats compared to the fasted rats, which is comparable with our findings (Ratnasooriya et al., 2004; Dayananda et al., 2008).

The rats treated with the leaf extract exhibited a significant tolerance following the oral administration of a glucose load. The highest reduction of glucose concentration following the glucose load was evident with the highest dose at the $4^{\text {th }}$ hour. The mechanism of action of this glucose tolerance effect exhibited by the extract may be due to the increased insulin synthesis or the secretion by pancreatic $\beta$-cells, or due to the enhanced glucose utilization by peripheral tissues or due to the increase in the production of glycogen in the liver. However, further investigations are required to confirm these mechanisms.

Investigation of the toxicological effects of A. lindleyana was carried out to determine the possible toxic effects that could occur due to the derangements of functions of the liver and kidneys in the long-term usage of the extract. During the experimental time period, rats did not exhibit any toxicity signs. Evidence obtained from the food intake, water intake, body weight, SGOT, SGPT, serum creatinine and blood urea nitrogen concentrations revealed that the administration of methanolic leaf extract of $A$. lindleyana for a period of one month has no renal, hepatic or other toxic effects on rats. Similar results have been reported with the stem bark extract of Kokoona zeylanica (Thanabhorn et al., 2006; Dayananda et al., 2008; Bakoma et al., 2013).

It is important to find out the phytochemicals that are present in the plant extract, since those are the chemicals responsible for the pharmacological actions of the plant. Preliminary phytochemical screening of the methanolic leaf extract of $A$. lindleyana revealed the presence of alkaloids, saponins, flavanoids and leucoanthocyanins. Previous studies have revealed that some plant flavonoids have a hypoglycaemic potential (Jung et al., 2006; Zhou et al., 2009; Lu et al., 2010; Salib et al., 2013). Flavonoids and tannins isolated from some plants that have a hypoglycaemic activity have been found to stimulate secretion or possess an effect similar to insulin (Marles \& Farnsworth, 1995). The hypolycaemic effect exhibited by $A$. lindleyana leaves may be due to the presence of flavonoids in the plant extract. However, further studies are required to confirm this view.

\section{Acknowledgement}

Mrs S. C. Higgoda, Senior Technical Officer, Department of Clinical Medicine, Faculty of Medicine, University of Colombo is kindly acknowledged for the support given to analyze the serum samples of toxicity studies.

\section{REFERENCES}

1. Badami S., Rai S.R. \& Suresh B. (2005). Antioxidant activity of Aporusa lindleyana root. Journal of Ethnopharmacology 101(1-3): 180 - 184.

DOI: http://dx.doi.org/10.1016/j.jep.2005.04.029

2. Bakoma B., Berke B., Gadegbeku K.E., Agbonon A., Aklikokou K., Gbeassor M., Creppy E.E. \& Moore E. (2013). Acute and sub-chronic (28 days) oral toxicity evaluation of hydroethanolic extract of Bridelia ferruginea Benth root bark in male rodent animals. Food and Chemical Toxicology 52: $176-179$.

DOI: http://dx.doi.org/10.1016/j.fct.2012.11.021

3. Barham D. \& Trinder P. (1972). An improved colour reagent for the determination of blood glucose by the oxidase system. Analyst 97(151): $142-145$.

DOI: http://dx.doi.org/10.1039/an9729700142

4. Bennett P.N. \& Brown M.J. (2003). Clinical Pharmacology, $9^{\text {th }}$ edition, pp. $687-688$. Churchill Livingstone, Oxford, UK.

5. Colledge N.R., Walker B.R. \& Ralston S.H. (2010). Davidson's Principles and Practice of Medicine, $21^{\text {st }}$ edition, pp. 798 - 803. Elsevier Limited, UK.

6. Dasanayake M.D. \& Clayton W.D. (1997). A Revised Handbook to the Flora of Ceylon, volume XI, pp. $270-$ 271. Oxford and IBN Publishing, New Delhi, India.

7. Dayananda P.D., Yapa W.B. \& Ratnasooriya W.D. (2008). 
The effect of the aqueous stem bark extract of Kokoona zeylanica thw. on the blood glucose level of mice. Pharmacognosy Magazine 4 (16): 308 - 314.

8. Department of Ayurveda (2004). Compendium of Medicinal Plants, A Sri Lankan Study, volume 4, pp. 30 - 33. Department of Ayurveda, Nawinna, Maharagama.

9. Dhawan B.N. \& Srimal R.C. (1984). The Use of Pharmacological Techniques for the Evaluation of Natural Products, pp. 66, 103 - 105. UNESCO, Lucknow, India.

10. Ediriweera E.R.H.S.S. \& Ratnasooriya W.D. (2009). A review on herbs used in treatment of diabetes mellitus by Sri Lankan ayurvedic and traditional physicians. Ayujournal 30(4): $373-391$.

11. Farnsworth N.R. (1978). Phytochemical Screening, pp. $1-$ 63. College of Pharmacy, University of Illinois, Chicago, USA.

12. Fernandopulle B.M.R., Karunanayake E.H. \& Ratnasooriya W.D. (1994). Oral hypoglycaemic effects of Mormodica dioica in the rat. Medical Science Research 22(2): 137 139.

13. Henry R.L., Cannon D.C. \& Winklemen J.W. (1974). Clinical Chemistry: Principles and Techniques, $2^{\text {nd }}$ edition, pp. 1288. Harper and Row, New York, USA.

14. Huang X.J., Choi Y.K., Im H.S., Yarimaga O., Yoon E. \& Kim H.S. (2006). Aspartate aminotransferase (AST/ GOT) and alanine aminotransferase (ALT/GPT) detection techniques. Sensors 6: $756-782$.

DOI: http://dx.doi.org/10.3390/s6070756

15. Jayakar B. \& Suresh B. (2003). Antihyperglycemic and hypoglycemic effect of Aporusa lindleyana in normal and alloxan induced diabetic rats. Journal of Ethnopharmacology 84(2-3): 247 - 249.

16. Jayakody J.R.A.C. \& Ratnasooriya W.D. (2008). Blood glucose level lowering activity of Sri Lankan black tea brew (Camellia sinensis) in rats. Pharmacognosy Magazine 4(16): $341-349$.

17. Joint Formulary Committee (2009). British National Formulary, pp. $367-386$. BMJ group and RPS Publishing, London, UK.

18. Jung U.J., Le M.K., Park Y.B., Kang M.A. \& Choi M.S. (2006). Effect of citrus flavonoids on lipid metabolism and glucose-regulating enzyme mRNA levels in type-2 diabetic mice. The International Journal of Biochemistry and Cell Biology 38(7): 1134 - 1145 .

DOI: http://dx.doi.org/10.1016/j.biocel.2005.12.002

19. Kasiviswanath R., Ramesh A. \& Kumar K.E. (2005). Hypoglycemic and antihyperglycemic effect of Gmelina asiatica Linn. in normal and in alloxan induced diabetic rats. Biological and Pharmaceutical Bulletin 28(4): 729 732.

DOI: http://dx.doi.org/10.1248/bpb.28.729

20. Kumar P. \& Clark M. (2009). Clinical Medicine, $7^{\text {th }}$ edition, pp. 1029 - 1030. Elsevier Limited, UK.

21. Lingadahalli P.S., Hosadu M.V., Basavaraja B.M. \& Vaidya
V.P. (2008). Evaluation of antimicrobial and analgesic activities of Aporusa lindleyana (euphorbiaceae) bark extract. International Journal of Green Pharmacy 2(3): $155-157$.

DOI: http://dx.doi.org/10.4103/0973-8258.42733

22. Lu Y.X., Zhang Q., Li J., Sun Y.X., Wang L.Y., Cheng W.M. \& Hu X.Y. (2010). Antidiabetic effects of total flavonoids from Litsea coreana leave on fat-fed, streptozotocininduced type 2 diabetic rats. American Journal of Chinese Medicine 38(4): 713 - 725.

DOI: http://dx.doi.org/10.1142/S0192415X10008184

23. Marles J.R. \& Farnsworth N.R. (1995). Antidiabetic plants and their active constituents. Phytomedicine 2(2): $123-$ 189.

24. Organisation for Economic Co-operation and Development (OECD) (2008). OECD Guidelines for Testing of Chemicals 407: Repeated Dose 28-Day Oral Toxicity Study in Rodents. Organisation for Economic Co-operation and Development, Paris, France.

25. Parasuraman S., Raveendran R. \& Kesavan R. (2010). Blood sample collection in small laboratory animals. Journal of Pharmacology and Pharmacotherapeutics 1: $87-93$. DOI: http://dx.doi.org/10.4103/0976-500X.72350

26. Peake M. \& Whiting M. (2006). Measurement of serum creatinine - current status and future goals. Clinical Biochemist Reviews 27(4): 173 - 184.

27. Rajagopal K., Sasikala K. \& Ragavan B. (2008). Hypoglycemic and antihyperglycemic activity of Nymphaea stellata flowers in normal and alloxan diabetic rats. Pharmaceutical Biology 46(9): 654 - 659.

DOI: http://dx.doi.org/10.1080/13880200802182554

28. Ratnasooriya W.D., Hettiarachchi H.D.I \& Jayakody J.R.A.C. (2004). Cassia fistula and hypoglycaemia. Australian Journal of Medical Herbalism 16(1): 8 - 13.

29. Salib J.Y., Michael H.N. \& Eskande E.F. (2013). Antidiabetic properties of flavonoid compounds isolated from Hyphaene thebaica epicarp on alloxan induced diabetic rats. Pharmacognosy Research 5(1): 22 - 29.

30. Sharma V., Pooja \& Marwaha A. (2011). Hypoglycemic activity of methanolic extracts of Nyctanthes arbor-tristis Linn. root in alloxan induced diabetic rats. International Journal of Pharmacy and Pharmaceutical Sciences 3(3): 210 - 212.

31. Thanabhorn S., Jaijoy K., Thamaree S., Ingkaninan K. \& Panthong A. (2006). Acute and subacute toxicity study of the ethanol extract from Lonicera japonica Thunb. Journal of Ethnopharmacology 107(1): 370 - 373. DOI: http://dx.doi.org/10.1016/j.jep.2006.03.023

32. Tietz N.W. (1976). Fundamentals of Clinical Chemistry, pp. 674 - 675, 991. W.B. Saunders Co., Philadelphia, USA.

33. Zhou T., Luo D., Li X. \& Luo Y. (2009). Hypoglycemic and hypolipidemic effects of flavonoids from lotus (Nelumbo nuficera Gaertn) leaf in diabetic mice. Journal of Medicinal Plants Research 3(4): 290 - 293. 